\title{
Influence of Desiccation Time on Survival and Regeneration of Embryonic Axes of Groundnut (Arachis hypogaea L.) Immersed in Liquid Nitrogen
}

\author{
M. M. Abdulmalik, I. S. Usman, J. D. Olarewaju, D. A. Aba
}

Department of Plant Science, Ahmadu Bello University, Zaria, Nigeria.

Email: uwa6474@yahoo.com

Received June $17^{\text {th }}, 2013$; revised July $17^{\text {th }}, 2013$; accepted August $5^{\text {th }}, 2013$

Copyright (C) 2013 M. M. Abdulmalik et al. This is an open access article distributed under the Creative Commons Attribution License, which permits unrestricted use, distribution, and reproduction in any medium, provided the original work is properly cited.

\begin{abstract}
Cryopreservation, the storage of biological materials in liquid nitrogen (LN), is a useful method for long term conservation of plant germplasm. This study was carried out with the objective of establishing an efficient desiccation technique for successful cryopreservation and recovery of embryonic axes of groundnut. Embryonic axes of four groundnut (Arachis hypogaea L.) genotypes were evaluated. The excised embryonic axes were dehydrated by air current of a laminar air flow cabinet for different duration $(0,1,2,3,4 \& 5 \mathrm{hrs})$ before being plunged in $\mathrm{LN}\left(-196^{\circ} \mathrm{C}\right)$ and held for $1 \mathrm{hr}$. Samples were thawed in water bath at $40^{\circ} \mathrm{C}$ for $2 \mathrm{~min}$, thereafter cultured on MS medium supplemented with $15 \mathrm{mg} / \mathrm{L}$ BAP for recovery. Highest survival $(96.67 \%-100 \%)$ and shoot formation $(91.67 \%-96.67 \%)$ were obtained at an average moisture content of $17 \%$ after $4-5 \mathrm{hr}$ desiccation. Among the genotypes evaluated, Samnut 22 and Samnut 23 recorded the highest survival and shoot formation. This technique therefore appears promising for cryopreservation of groundnut germplasm.
\end{abstract}

Keywords: Cryopreservation; Groundnut; Embryonic Axes; Desiccation

\section{Introduction}

Groundnut (Arachis hypogaea L.) is an important source of protein and edible oil in the world. Nigeria ranks third after India and China in terms of production [1]. Conservation of groundnut ensures availability of germplasm for future breeding needs, and seeds are the most preferred propagule used by seed bank curators for its storage. However, even under seed bank condition, long term storage of groundnut is not feasible as viability losses frequently occur [2]. This is because of its high oil content $(45 \%-50 \%)$, which makes it more perishable and prone to rapid loss of both quality and viability in storage [3]. For this reason, groundnut germplasm is maintained by planting every season in the Institute for Agricultural Research (IAR). This is not only laborious, time consuming and expensive, but also plants are exposed to the possible risk of pest, disease and environmental stresses. Newly improved genotypes of crops are fast replacing traditional genotypes or landraces which are often the source of diversity that breeders use for crop improvement. The need to conserve groundnut and other crop biodiversity therefore becomes imperative. Thus, cryopreservation should be considered as important complimentary strategy for ex situ conservation. Cryopreservation is used for long-term storage at ultralow temperature of $-196^{\circ} \mathrm{C}$ [4]. Cell division and metabolic activities are stopped when plants are exposed to ultra-low temperatures, allowing storage without alteration for an indefinite period of time [5]. Desiccation of excised embryos and embryonic axes is one of the most practicable techniques for cryopreservation [6]. Desiccation technique has been applied to a wide range of plant taxa which include embryonic axes of citrus [7,8] almond [9] and embryos of maize [10]. The present work is aimed at establishing an efficient desiccation technique for cryopreservation of embryonic axes of groundnut.

\section{Materials and Methods}

Seeds of four groundnut (Arachis hypogaea L.) genotypes were obtained from the groundnut breeding unit of IAR and used for this experiment. The seeds were surface sterilized by sequential treatment for $5 \mathrm{~min}$ in $70 \%$ 
alcohol, $20 \mathrm{~min}$ in $10 \% \mathrm{NaOCl}$ (commercial bleach) plus 2 - 3 drops of tween 20 , rinsed thrice with sterile distilled water and immersed in $5 \% \mathrm{NaOCl}$ plus $2-3$ drops of tween 20 for $10 \mathrm{~min}$ with occasional stirring and washed three times with sterile distilled water. Thereafter seeds were soaked in sterile distilled water for $3 \mathrm{hr}$. Embryonic axes were excised and subjected to desiccation under the air current of a laminar flow cabinet for $0,1,2,3,4$ and 5 $\mathrm{hr}$ exposure period. Moisture content (MC) was determined on fresh weight basis after drying in a $100^{\circ} \mathrm{C}$ oven for $24 \mathrm{hr}$ with 3 replicates of 10 embryonic axes per duration. Desiccated and nondesiccated (0) embryonic axes were placed in $2 \mathrm{ml}$ sterile cryovial and directly immersed into liquid nitrogen $\left(-196^{\circ} \mathrm{C}\right)$ and held for $1 \mathrm{hr}$. Thawing took place in a water bath at $40^{\circ} \mathrm{C}$ for $2 \mathrm{~min}$. Embryonic axes were cultured individually in test tubes containing $10 \mathrm{ml}$ of MS medium [11] supplemented with $15 \mathrm{mg} / \mathrm{L}$ 6-benzylaminopurine (BAP) and solidified with $8 \mathrm{~g} / \mathrm{L}$ agar. Cultures were maintained in a growth chamber at $26^{\circ} \mathrm{C} \pm 2{ }^{\circ} \mathrm{C}$ under $16 \mathrm{hr}$ light $/ 8 \mathrm{hr}$ dark photo period provided by white inflorescence. Three replicates of $10 \mathrm{em}$ bryonic axes were used per treatment. Survival was determined by the appearance of green color, increase in size, callusing and development of the root or shoot pole and expressed as a percentage of the total number of embryonic axes that survived within two weeks of culturing.
While shoot formation was expressed as a percentage of the total number of embryonic axes forming shoots within one month of culturing. Data collected were subjected to analysis of variance (ANOVA) and means compared using Duncan's Multiple Range Test [12].

\section{Results and Discussion}

ANOVA for moisture content, survival and shoot formation of cryopreserved embryonic axes of groundnut is presented in Table 1. The main effects of desiccation and genotype were highly significant $(p \leq 0.01)$ for all the characters. Two-way interaction between the desiccation time and genotype was also significant for all the characters.

Desiccation rates significantly influenced the extent of water loss of embryonic axes of groundnut, their survival and subsequent shoot formation after storage in liquid nitrogen (Table 2). Nondesiccated embryonic axes of groundnut failed to survive liquid nitrogen storage. This result corroborates that of Gagliardi, who observed nonsurvival of nondehydrated and cryopreserved embryonic axes of Arachis species [13]. Lack of germination of nondesiccated plant material has also been reported in other crops $[14,15]$. Similarly, embryonic axes desiccated for $1 \mathrm{hr}$ also failed to survive the cryogenic treatment.

Table 1. Analysis of variance for moisture content, survival and shoot formation of cryopreserved embryonic axes of groundnut.

\begin{tabular}{ccccc}
\hline \multirow{2}{*}{ Source of variation } & \multirow{2}{*}{ Degree of freedom } & \multicolumn{3}{c}{ Mean Square } \\
\cline { 3 - 5 } & & Moisture content (\%) & Survival (\%) & Shoot formation (\%) \\
\hline Desiccation(D) & 5 & $1060.57^{* *}$ & $131597.01^{* *}$ & $116536.55^{* *}$ \\
Genotype (G) & 3 & $99.60^{* *}$ & $2539.94^{* *}$ & $2410.05^{* *}$ \\
D x G & 15 & $150.15^{* *}$ & $3603.66^{* *}$ & $2163.56^{* *}$ \\
Error & 48 & $156.00^{* *}$ & $1575.00^{* *}$ & $489.99^{* *}$ \\
\hline
\end{tabular}

${ }^{* *} \mathrm{P} \leq 0.01$.

Table 2. Effect of desiccation rate on moisture content, survival and shoot formation of cryopreserved embryonic axes of groundnut.

\begin{tabular}{cccc}
\hline Treatment & Moisture content (\%) & Survival (\%) & Shoot formation (\%) \\
\hline Time of desiccation (hr) (D) & & & $0.00 \mathrm{e}$ \\
0 & $27.33 \mathrm{a}$ & $0.00 \mathrm{~d}$ & $0.00 \mathrm{e}$ \\
1 & $22.50 \mathrm{~b}$ & $0.00 \mathrm{~d}$ & $59.35 \mathrm{~d}$ \\
2 & $18.25 \mathrm{c}$ & $76.12 \mathrm{c}$ & $78.75 \mathrm{c}$ \\
3 & $17.42 \mathrm{c}$ & $83.75 \mathrm{~b}$ & $91.67 \mathrm{~b}$ \\
4 & $17.25 \mathrm{c}$ & $96.67 \mathrm{a}$ & $96.67 \mathrm{a}$ \\
5 & $16.67 \mathrm{c}$ & $100 \mathrm{a}$ & 1.30 \\
\hline
\end{tabular}

Means followed by the same letter(s) within a column are not significantly different at $\mathrm{P}<0.05$ level of significance using DMRT. 
Their nonsurvival could be attributed to the insufficient loss of moisture at this period which caused formation of lethal ice crystals that damage the cells during liquid nitrogen storage or thawing. Insufficient dehydration of the explants prior freezing may cause the formation of ice crystals during freezing or warming leading to the destruction of cellular structures and death of the explant [16]. Desiccation of embryonic axes from $2 \mathrm{hr}$ to $5 \mathrm{hr}$ rapidly caused significant loss of moisture content. This greatly improved the survival and shoot formation of cryopreserved embryonic axes. The highest survival (96.67\% - $100 \%$ ) and subsequent shoot formation (91.67\% $96.67 \%$ ) was obtained at an average moisture content of $17 \%$ after 4 - $5 \mathrm{hr}$ desiccation rates. [17] reported 100\% germinability of embryonic axes when moisture content was reduced from $25 \%$ to $8.5 \%$ which was achieved at $2.5 \mathrm{hr}$ desiccation time. While [13], reported $80 \%$ shoot development at $18 \%$ moisture content after $1 \mathrm{hr}$ desiccation rate in Arachis species. The improved survival and shoot formation with decreasing moisture content could be due to increased accumulation of sugars during drying. As it is possible that accumulation of sugars may serve to maintain cellular integrity by osmotically decreasing cell volume, or act directly to protect by stabilization of membranes [18]. Another possibility is the probable accumulation of abscisic acid (ABA) in the desiccated em- bryos. ABA is reported to promote desiccation tolerance in mature embryo through the synthesis of late embryogenesis abundant (LEA) proteins encoded by mRNA [19], ABA has also been implicated in cold acclimation in plants [20].

The moisture content of excised embryonic axes is the most critical factor influencing the success of cryopreservation using desiccation protocol. This to some extent is influenced by the desiccation rate. Results from correlation studies (Table 3) indicate that moisture content was negatively correlated with survival and shoot formation of embryonic axes after cryopreservation $(\mathrm{r}=-0.41$ and -0.35 , respectively). This implies that any significant loss of moisture will greatly improve survival and subsequent shoot formation of cryopreserved embryonic axes of groundnut. Therefore samples to be cryopreserved must be sufficiently dehydrated to avoid lethal intracellular freezing. [21] reported that, survival and emergence of post-thaw embryos were closely related to their moisture contents prior to freezing.

Results obtained from this study showed a significant difference among the genotypes evaluated (Figure 1). Samnut 22 embryonic axes recorded the highest moisture content, which was statistically the same as that of Samnut 10 and Samnut 21. This was followed by Samnut 23. Similarly, significant survival and shoot formation of

Table 3. Correlation coefficients between moisture content, survival and shoot formation of groundnut as influenced by desiccation.

\begin{tabular}{cccc}
\hline & Moisture content (\%) & Survival (\%) & Shoot formation (\%) \\
\hline Moisture content (\%) & 1.00 & & \\
Survival (\%) & -0.41 & 1.00 & 1.00 \\
Shoot formation (\%) & -0.35 & 0.98 & \\
\hline
\end{tabular}

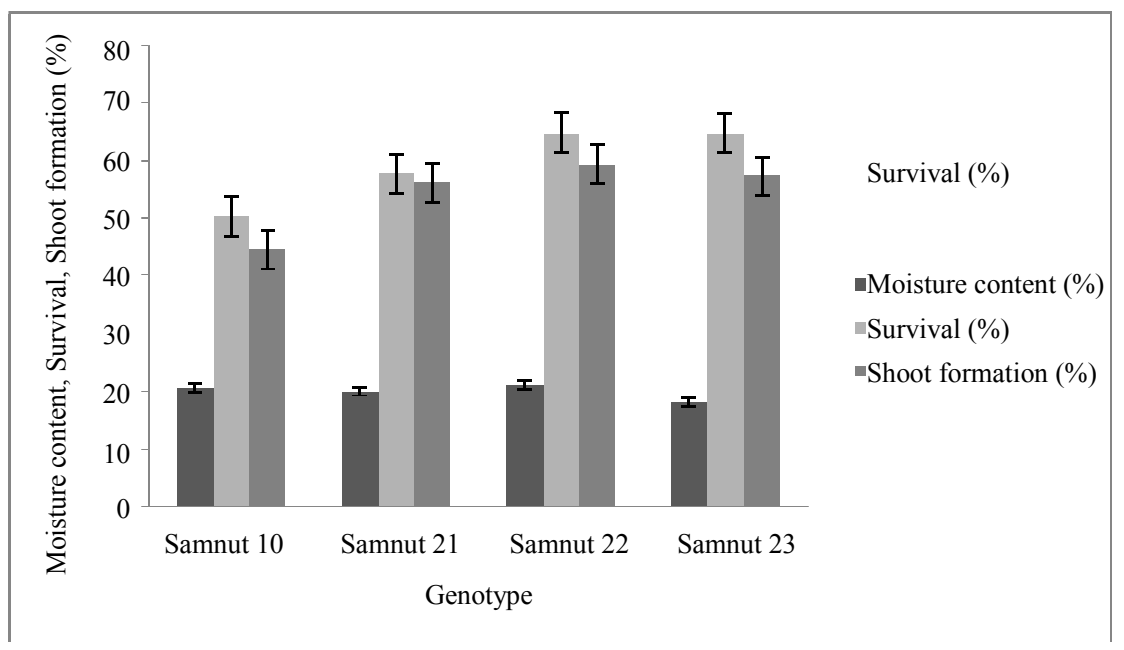

Figure 1. Influence of genotype on moisture content, survival and shoot formation of cryopreserved embryonic axes of groundnut. 
cryopreserved embryonic axes was observed among the genotypes. Samnut 22 and Samnut 23 which are at par with each other had the highest survival and shoot formation followed by Samnut 21. While Samnut 10 had a relatively lower survival and shoot formation. The observed differences among the genotypes could be due to genotypic influence, as tissue culture response in groundnut is strongly influenced by the plant genotype $[22,23]$. Genotypic influence has also been reported in cryopreserved embryonic axes of maize [24]. There was a significant interaction between the genotypes and time of desiccation for moisture content of cryopreserved embryonic axes of groundnut. Samnut 10 had the highest moisture content prior to desiccation which was comparable to that recorded by Samnut 22, followed by Samnut 21 and Samnut 23. At $1 \mathrm{hr}$ desiccation time Samnut 10 significantly had higher moisture content compare to the other genotypes, from $2 \mathrm{hr}$ to $5 \mathrm{hr}$ desiccation time all the genotypes recorded comparable low moisture content (Table 4). The genotype $x$ desiccation interaction on survival clearly indicated that embryonic axes of all the genotypes did not survive cryopreservation when none desiccated and when desiccated for $1 \mathrm{hr}$ (Table 5). However, at $2 \mathrm{hr}$ and $3 \mathrm{hr}$ desiccation time Samnut 22 and Samnut 23 comparably recorded the highest survival rates compare to the other genotypes. While from $4 \mathrm{hr}$ to $5 \mathrm{hr}$ desiccation time, all the genotypes comparably recorded very high survival rates. Effect of genotype $\mathrm{x}$ desiccation interaction on shoot formation of cryopreserved embryonic axes was significant (Table 6). Samnut 21, Samnut 22 and Samnut 23 comparably produce more shoots than Samnut 10 when desiccated for $2 \mathrm{hr}$. At $3 \mathrm{hr}$ desiccation time Samnut 22 and Samnut 23 had higher shoot formation than Samnut 21 followed by Samnut 10. All the groundnut genotypes comparably recorded high shoot formation at $4 \mathrm{hr}$ desiccation time, with the exception of Samnut 10 which significantly re-

Table 4. Effect of genotype $x$ desiccation interaction on the moisture content of cryopreserved embryonic axes of groundnut.

\begin{tabular}{lcccccc}
\hline \multicolumn{7}{c}{ Treatment level } \\
\hline \multirow{2}{*}{ Tenotype of desiccation } & & & \\
\cline { 2 - 7 } & 0 & 1 & 2 & 3 & 4 & 5 \\
\hline Samnut 10 & $31.33 \mathrm{a}$ & $24.67 \mathrm{~b}$ & $18.67 \mathrm{c}$ & $17.67 \mathrm{c}$ & $16.00 \mathrm{c}$ & $15.67 \mathrm{c}$ \\
Samnut 21 & $26.00 \mathrm{~b}$ & $22.00 \mathrm{bc}$ & $18.33 \mathrm{c}$ & $17.00 \mathrm{c}$ & $17.67 \mathrm{c}$ & $18.33 \mathrm{c}$ \\
Samnut 22 & $27.67 \mathrm{ab}$ & $26.00 \mathrm{~b}$ & $19.00 \mathrm{c}$ & $18.67 \mathrm{c}$ & $18.00 \mathrm{c}$ & $17.00 \mathrm{c}$ \\
Samnut 23 & $24.33 \mathrm{~b}$ & $17.33 \mathrm{c}$ & $17.00 \mathrm{c}$ & $16.33 \mathrm{c}$ & $17.33 \mathrm{c}$ & $15.67 \mathrm{c}$ \\
\hline
\end{tabular}

Means followed by the same letter(s) are not significantly different at $\mathrm{P}<$ 0.05 level of significance using DMRT.
Table 5. Effect of genotype $x$ desiccation interaction on the survival of cryopreserved embryonic axes of groundnut.

\begin{tabular}{cccccccc}
\hline & \multicolumn{7}{c}{ Treatment level } \\
\cline { 2 - 8 } Genotype & \multicolumn{7}{c}{ Time of desiccation } \\
\cline { 2 - 8 } & 0 & 1 & 2 & 3 & 4 & 5 \\
\hline Samnut 10 & $0 \mathrm{e}$ & $0 \mathrm{e}$ & $53.83 \mathrm{~d}$ & $60 \mathrm{~cd}$ & $86.67 \mathrm{ab}$ & $100 \mathrm{a}$ \\
Samnut 21 & $0 \mathrm{e}$ & $0 \mathrm{e}$ & $71.43 \mathrm{c}$ & $75 \mathrm{bc}$ & $100 \mathrm{a}$ & $100 \mathrm{a}$ \\
Samnut 22 & $0 \mathrm{e}$ & $0 \mathrm{e}$ & $88.89 \mathrm{ab}$ & $100 \mathrm{a}$ & $100 \mathrm{a}$ & $100 \mathrm{a}$ \\
Samnut 23 & $0 \mathrm{e}$ & $0 \mathrm{e}$ & $88.33 \mathrm{ab}$ & $100 \mathrm{a}$ & $100 \mathrm{a}$ & $100 \mathrm{a}$ \\
\hline
\end{tabular}

Means followed by the same letter(s) are not significantly different at $\mathrm{P}<$ 0.05 level of significance using DMRT.

Table 6. Effect of genotype $x$ desiccation interaction on the shoot formation of cryopreserved embryonic axes of groundnut.

\begin{tabular}{ccccccc}
\hline \multirow{6}{*}{ Genotype } & \multicolumn{7}{c}{ Trime of desiccation } \\
\cline { 2 - 7 } & 0 & 1 & 2 & 3 & 4 & 5 \\
\hline Samnut 10 & 0f & 0f & $47.50 \mathrm{e}$ & $60.00 \mathrm{~cd}$ & $70.00 \mathrm{bc}$ & $90 \mathrm{a}$ \\
Samnut 21 & 0f & 0f & $62.50 \mathrm{~cd}$ & $75 \mathrm{~b}$ & $100 \mathrm{a}$ & $100 \mathrm{a}$ \\
Samnut 22 & 0f & 0f & $66.67 \mathrm{bcd}$ & $90 \mathrm{a}$ & $100 \mathrm{a}$ & $100 \mathrm{a}$ \\
Samnut 23 & 0f & 0f & $60.71 \mathrm{~cd}$ & $90 \mathrm{a}$ & $96.67 \mathrm{a}$ & $96.67 \mathrm{a}$
\end{tabular}

Means followed by the same letter(s) are not significantly different at $\mathrm{P}<$ 0.05 level of significance using DMRT.

corded the least shoot formation. However, at $5 \mathrm{hr}$ desiccation time, all the groundnut genotypes recorded comparably high shoot formation after cryopreservation. This suggests that the effect of time of desiccation was not uniform over the different genotypes.

The survived and regenerated shoots after 4 weeks were rooted on MS medium supplemented with $1 \mathrm{mg} / \mathrm{L}$ 1-naphthaleineacetic acid (NAA) [25]. These were then transferred to potty soil (riverside sand) for hardening. No morphological abnormalities were observed in the plants developed from cryopreserved embryonic axes by desiccation (Figures 2-5).

\section{Conclusions}

Results obtained in this study indicate significant genotypic differences in response to the desiccation rates.

However, in view of the very high survival $(96.67 \%$ $100 \%)$ and shoot regeneration $(91.67 \%-96.67 \%)$ obtained in the groundnut genotypes, it can be concluded that cryopreservation using desiccation protocol can be successfully applied to groundnut, and the provided moisture content is reduced to about $17 \%$. Hence, this 


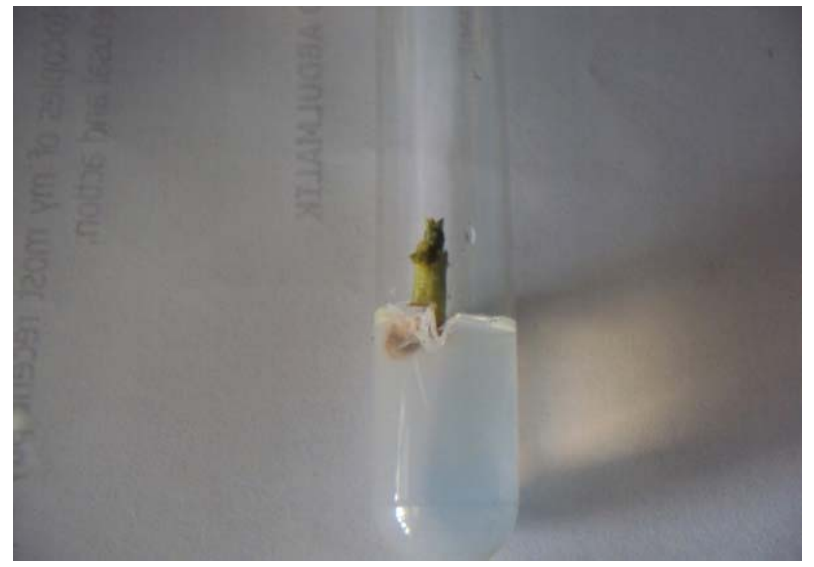

Figure 2. Microshoot regeneration from cryopreserved embryonic axes on MS + $15 \mathrm{mg} / \mathrm{L}$ BAP after 2 wk culture.

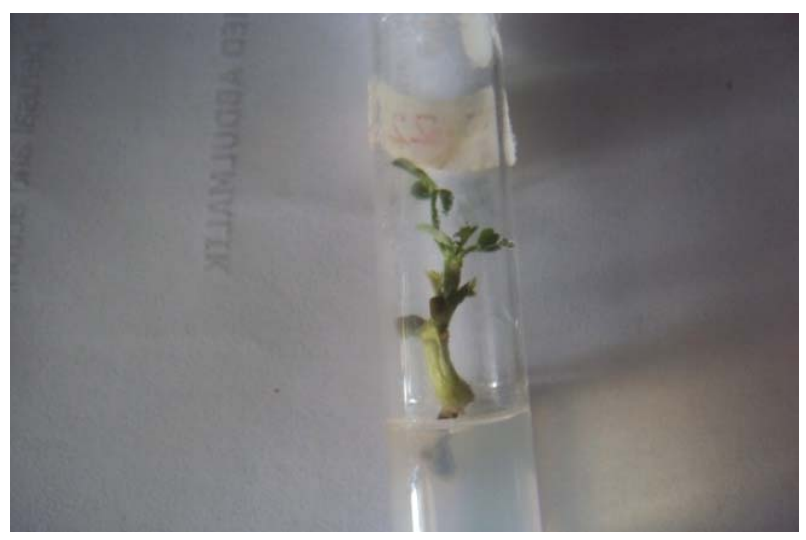

Figure 3. Microshoot on MS + $15 \mathrm{mg} / \mathrm{L}$ BAP after 4 wk culture.

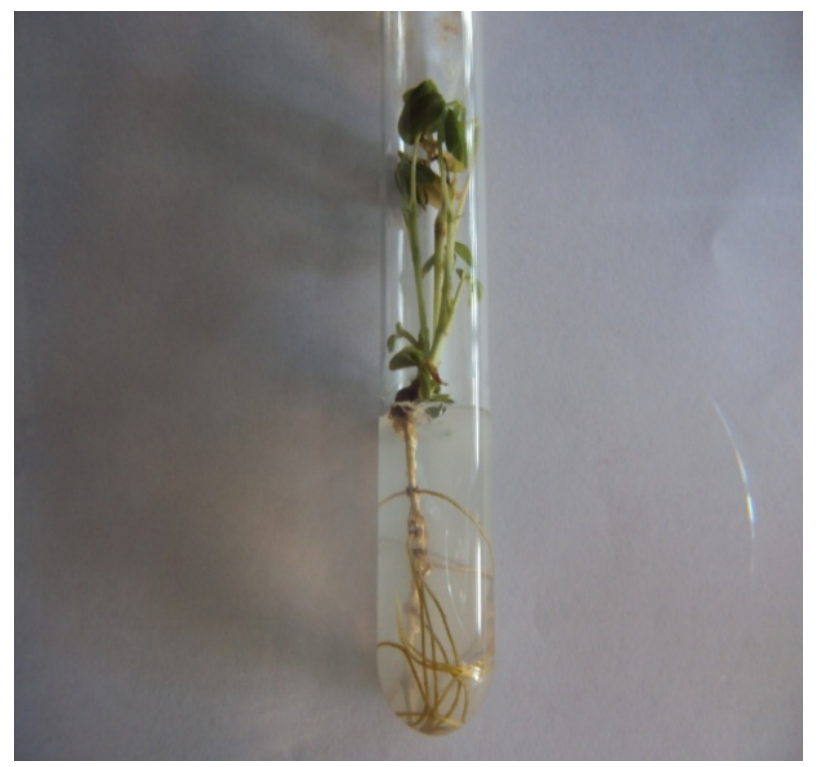

Figure 4. Regenerated Plantlet rooted on $\mathrm{MS}+1 \mathrm{mg} / \mathrm{L}$ NAA.

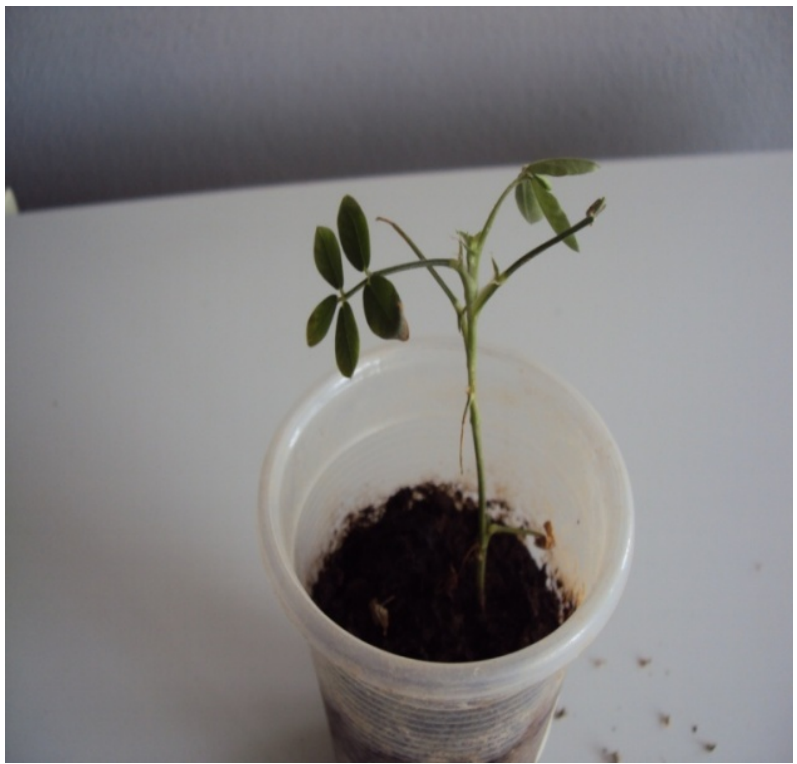

Figure 5. A potted plant in green house.

technique could be routinely employed for conservation of groundnut germplasm.

\section{Acknowledgements}

The authors acknowledge the Institute for Agricultural Research, Ahmadu Bello University Zaria, Nigeria for funding this research.

\section{REFERENCES}

[1] FAOSTAT, 2011. http://faostat.fao.org/default.aspx

[2] J. B. Morris, S. Dunn and R. N. Pittman, "Plant Recovery from Embryonic Axes of Deteriorated Peanut Seed for Germplasm Renewal," Peanut Science, Vol. 22, No. 1, 1995, pp. 66-70. doi:10.3146/pnut.22.1.0015

[3] M. A. Perez and J. A. Arguello, "Deterioration of Peanut (Arachis hypogaea L. cv. Florman) Seed under Natural and Accelerated Aging," Seed Science and Technology, Vol. 23, No. 2, 1995, pp. 439-445.

[4] F. Engelmann, "Plant Cryopreservation: Progress and Prospects," In Vitro Cellular Developmental Biology-Plant, Vol. 40, No. 5, 2004, pp. 427-433. doi:10.1079/IVP2004541

[5] N. R. F. Castillo, N. V. Bassil, S. Wada and B. M. Reed, "Genetic Stability of Cryopreserved Shoot Tips of Rubus Germplasm," In Vitro Cellular and Developmental Bioliogy-Plant Vol. 46, No. 3, 2010, pp. 246-256.

[6] M. N. Normah and A. M. Makeen, "Cryopreservation of Excised Embryos and Embryonic Axes," In: B. M. Reed, Ed., Plant Cryopreservation: A Practical Guide, Vol. 18, 2008, pp. 211-220. doi:10.1007/978-0-387-72276-4_10

[7] A. M. Makeen, M. N. Normah, S. Dussert and M. M. Clyde, "Cryopreservation of Whole Seeds and Excised 
Embryonic Axes of Citrus suhuensis cv. Limau Langkat in Accordance to Their Desiccation Sensitivity," Cryo Letters, Vol. 26, No. 4, 2005, pp. 259-268.

[8] O. M. Alzoubi and M. N. Normah, "Desiccation Sensitivity of Cryopreservation of Excised Embryonic axes of Citrus suhuiensis cv. Limau Madu, Citrumelo [Citrus paradisi Macf. x Poncirus trifoliate (L.) Raf] and Fortunella polyandra," Cryo Letters, Vol. 33, No. 3, 2012, pp. 240-250.

[9] R. Chaudhury and K. P. S. Chandel, "Cryopreservation of Embryonic Axes of Almond (Prunus amygdalus Batsch.) Seeds," Cryo Letters, Vol. 16, No. 1, 1995, pp. 51-56.

[10] B. Wen and S. Song, "Acquisition of Cryotolerance in Maize Embryos during Seed Development," Cryo Letters, Vol. 28, No. 2, 2007, pp. 109-118.

[11] T. Murashige and F. Skoog, "A Revised Medium for Rapid Growth and Bioassays with Tobacco Tissue Cultures," Physiologia Plantarum, Vol. 15, No. 43, 1962, pp. 473-497. doi:10.1111/j.1399-3054.1962.tb08052.x

[12] D. B. Duncan, "Multiple Range and Multiple F-Test," Biometrics, Vol. 11, No. 1, 1955, pp. 1-42. doi: $10.2307 / 3001478$

[13] R. F. Gagliardi, G. P. Pacheco, J. F. M. Vall and E. Mansur, "Cryopreservation of Cultivated and Wild Arachis Species Embryonic Axes Using Desiccation and Vitrification Methods," Cryo Letters, Vol. 23, No. 1, 2002, pp. 61-68.

[14] M. Azimi, C. O’Brien, S. Ashmore and R. Drew, "Cryopreservation of Papaya Germplasm," In: W. C. Chang and R. Drew, Eds., IInd IS on Biotechnology of Tropical \& Subtropical Species, 2005, pp. 43-50. wwwlib.teiep.gr/stories/acta/Acta 692/692_4.pdf

[15] D. Dumet, F. Engelmann, N. Chabrillange and Y. Duval, "Cryopreservation of Oil Palm (Elaeis guineensis Jacq.) Somatic Embryos Involving a Desiccation Step," Plant Cell Reports, Vol. 12, No. 6, 1993, pp. 352-355. doi:10.1007/BF00237434

[16] A. Halmagyi, S. Vălimăreanu, A. Coste, C. Deliu and V. Isac, "Cryopreservation of Malus Shoots Tips and Subsequent Plant Regeneration," Romanian Biotechnological Letters, Vol. 15, No. 1, 2010, pp. 79-85.

[17] E. A. Ozudogru, Y. Ozden-Tokatli, F. Gumusel, C. Benelli and M. Lambardi, "Development of a Cryopreserva- tion Procedure for Peanut (Arachis hypogaea L.) Embryonic Axes and Its Application to Local Turkish Germplasm," Advances in Horticultural Science, Vol. 23, No. 1, 2009, pp. 41-48.

[18] R. E. L. Percy, N. J. Livingston, A. Jonathan, J. A. Moran and P. Von Aderkas, "Desiccation, Cryopreservation and Water Relations Parameters of White Spruce (Piced glauca) and Interior Spruce (Picea glauca $\times$ Engelmannii Complex) Somatic Embryos," Tree Physiology, Vol. 21, No. 18, 2001, pp. 1303-1310. doi:10.1093/treephys/21.18.1303

[19] L. Taiz and E. Zeiger, "Plant Physiology: Auxins," 3rd Edition, Macmillan Publishing Co., New York, 2003, p. 544.

[20] X. Xue-Xuan, S. Hong-Bo, M. Yuan-Yuan, X. Gang, S. Jun-Na, G. Dong-Gang and R. Cheng-Jiang, "Biotechnological Implications from Abscisic Acid (ABA) Roles in Cold Stress and Leaf Senescence as an Important Signal for Improving Plant Sustainable Survival under AbioticStressed Conditions," Critical Reviews in Biotechnology, Vol. 30, No. 3, 2010, pp. 222-230. doi: $10.3109 / 07388551.2010 .487186$

[21] B. Wen and S. Song, "Acquisition and Loss of Cryotolerance in Livistona chinensis Embryos during Seed Development," Cryo Letters, Vol. 28, No. 4, 2007, pp. 291302.

[22] L. A. Mroginsky, K. K. Kartha and J. P. Shyluk, "Regeneration of Peanut (Arachis hypogaea L) Plantlets in Vitro Culture of Immature Leaves," Canadian Journal of Botany, Vol. 59, No. 5, 1981, pp. 826-830.

[23] P. Banerjee, S. Maity, S. S. Maiti and N. Banerjee, "Influence of Genotype on in Vitro Multiplication Potential of Arachis hypogaea L.," Acta Botanica Croatica, Vol. 66, No. 1, 2007, pp. 15-23.

[24] M. M. Abdulmalik, I. S. Usman, J. D. Olarewaju and D. A. Aba, "Effect of Naphthalene Acetic Acid (NAA) on in Vitro Rooting of Regenerated Microshoots of Groundnut (Arachis hypogaea L.)," Bayero Journal of Pure and Applied Sciences, Vol. 5, No. 2, 2012, pp. 128-131.

[25] I. S. Usman and M. M. Abdulmalik, "Cryopreservation of Embryonic Axes of Maize (Zea maize L.) by Vitrification Protocol," African Journal of Biotechnology, Vol. 9, No. 52, 2010, pp. 8955-8957. 